\title{
Theoretical and practical aspects of the formation of an integrated quality management system in milk processing enterprises
}

\author{
Olga Mohylevska ${ }^{1}$, George Abuselidze ${ }^{2, *}$, Olena Dragan ${ }^{3}$, Vasil Gorovij ${ }^{4}$, and Vitalii \\ Opanasiuk $^{1}$ \\ ${ }^{1}$ Kiev International University, Kyiv, Ukraine \\ ${ }^{2}$ Batumi Shota Rustaveli State University, Batumi, Georgia \\ ${ }^{3}$ National University of Food Technology, Kyiv, Ukraine \\ ${ }^{4}$ National University of Life and Environmental Sciences of Ukraine, Kiev, Ukraine
}

\begin{abstract}
The article is devoted to the study of theoretical and practical aspects of building an integrated quality management system at milk processing enterprises. It is proved that quality management is a continuous process of influencing production by consistently implementing logically interrelated functions to ensure quality. An integrated quality management system is a set of structures and procedures, processes and resources required to implement quality management. It should be an integral part of the enterprise management system and should provide the management of the organization and / or the consumer with confidence that the product or service will meet the established quality requirements. It is proved that in the process of making a decision on the organization's quality management system, measures are defined and planned to achieve the goals. The combination of these activities makes up the plan of organizational activity. For each of the activities included in the plan, the conditions for implementation and responsibility for implementation are determined. Since the quality management system actually covers all areas of the organization, then, of course, the processes of creating and implementing a quality management system in the enterprise will be associated with a change in the organizational structure of management.
\end{abstract}

\section{Introduction}

In modern economic conditions, quality has become an integrative concept that affects the interests of all participants in the national economy. For manufacturers, quality is a guarantee and a decisive factor in ensuring their competitiveness, sustainability, trust and success. For consumers, improving quality is a necessary condition for meeting their needs and protecting their rights, and for improving the quality of life of citizens, it is one of the priority tasks of the state. Current problems of quality management, the formation and implementation of integrated quality management systems in organizations were considered

\footnotetext{
${ }^{*}$ Corresponding author : george.abuselidze@gmail.com
} 
in the works of both domestic scientists and foreign specialists. In particular, among them are: J. Priede, V. Siva, I. Gremyr, B. Bergquist, R. Garvare, T. Zobel, R. Isaksson, W. Fan, F. Geerts, G. Abuselidze, Y. Bilyak, N.K. Mračkovskaya, A. Slobodianyk, V. Lymar, C. Zehir, Ö.G. Ertosun, S. Zehir, B. Müceldilli [1-6]. The results of many years of research on the activities of many enterprises conducted by scientists, in particular V. Nanda, M.S. Ilkay, E. Aslan, J.A. Gimenez-Espin, D. Jiménez-Jiménez, M. Martinez-Costa, A. Slobodianyk, P. Kumar, J. Maiti, A. Gunasekaran and others [7-11] indicate that improving the quality management system, improving the quality of business processes of production activities, products and services leads to an increase in the number of consumers and a long trend of increasing income [12]. At the same time, the issues of building integrated quality management systems at enterprises in accordance with the requirements and criteria of the international standards ISO 9000 and ensuring their effective functioning remain in the domestic scientific sources of little concern.

The solution of the most important problems of quality improvement is possible if an effective quality management system is implemented. In accordance with the international standards ISO 9000, the quality management system is a world-famous security mechanism that ensures high quality, processes, work and services. The implementation of such systems should be a strategic decision in the organization.

The most common are the standardized approaches of quality management systems (ISO 9001), environmental management (ISO 14001), occupational health and safety (OHSAS 18001, BS 8800, ILO'OSH). There are standards for social responsibility management systems (SA 8000, IS 10000), information responsibility management standards (BS 6079b1, 2, 3: 2000; IEC 62198: 2002), risk management in corporate governance (PD 6668: 2000), knowledge management, records management (ISO 15489b1 2001) [13].

The purpose of the scientific article is the theoretical and practical aspects of the formation and construction of an integrated quality management system and recommendations for ensuring its effective functioning at milk processing enterprises.

\section{Materials and Methods}

The objectives of the study in accordance with these problems and the relevance of the study is: definition of the essence of the quality management system and the need to build it in the enterprise; general characteristics of the basics of building, implementing and improving the efficiency of quality management systems in the enterprise; general characteristics of the basics of building, implementing and improving the efficiency of quality management systems in the enterprise; propose measures to improve the organizational support for the development and implementation of a quality management system at milk processing enterprises.

The solution of the indicated tasks in the scientific article is provided by the use of general scientific and special research methods. In particular: methods of system analysis (to consider the problem of using quality management systems as an element of the enterprise management system); factor analysis (to identify factors that affect the process of implementing the quality system in the enterprise and management); logical generalization (to define the essence, criteria, and principles of quality management); statistical methods of quality analysis (to identify the causes of problems in quality management, their systematization and generalization); expert assessments (to summarize the results of the expert survey and determine the motivation for the implementation of quality management systems, improving the effectiveness of work); technical and economic calculations (to determine the effectiveness of the implementation and operation of integrated quality management systems in the enterprise). 


\section{Results and Discussion}

Building a quality management system (QMS) and its application is a very effective tool for the evolutionary improvement of processing enterprises. The development of a quality management system contributes to the optimization of the company, ensures the competitiveness of its products (services), increases efficiency and demonstrates to potential consumers that the company can consistently produce products of appropriate quality, that is, one that meets all its needs. In a market economy, manufacturers are constantly affected by the competitive environment, which requires them to pay more attention to quality issues. Recently, the management of many companies meets the need for quality management as a means of achieving competitiveness in the market and gaining consumer confidence in products.

Today, the most effective way to improve corporate governance is to implement integrated management systems created in accordance with the requirements of international standards: ISO 9000, ISO 14000, OHSAS 18000 and others. These standards are based on the world experience of management and are recommendations for improving the company's management activities. The ISO 9000 series of standards have established a unique, world-renowned approach to the terms of the contract for the evaluation of the quality system and at the same time regulate the relationship between manufacturers and consumers of products. The main purpose of the quality system, based on the ISO 9000 series standards, is based on ensuring the quality of products needed by consumers, and bringing the company's ability to do so. In the ISO 9000 series of standards, the costeffectiveness targets are very weak, and the delivery time is simply scarce.

Scientific justification and a clear understanding of the concept of "product quality" is important for standardization, certification, consumer protection, and the practice of concluding purchase and sale transactions, since it allows you to identify the necessary minimum of criteria that quality products must meet. With this in mind, different interpretations of this concept should be considered. Among American experts, there is a point of view that quality is a category that is not subject to objective expression and everyone determines it at their own discretion. For example, F. Crosby defines it as "compliance with the requirements", E. Deming believes that "excellence means getting the level of quality that the market expects", A. Feigenbaum calls quality "a set of market, technical, production and operational characteristics of a product (or service), thanks to which the product, used (or service) meets the expectations of the consumer". The American Society for Quality Control and the American Standards Institute define quality as "the set of properties and characteristics of a product (or service) that determine its ability to meet certain needs" $[14,15]$.

Ukrainian experts in the field of quality management define product quality as the degree of cost, value, suitability of something for its intended use, or as a set of characteristics of products or services according to their ability to meet the established and expected needs of consumers. Recently, the literature draws attention to the need to understand the different content and technical and economic concept of "quality". Most often, when interpreting the concept of "quality", one should proceed from various aspects of its understanding, namely: philosophical, social, technical, economic and legal [15].

In modern conditions, companies operating on the global market are increasingly using the system of "Total Quality Management" (TQM), which is the result of a symbiosis of Western and Eastern concepts of product quality management. This overall management system, where quality management, quality improvement and quality assurance policies play an important role in the corporate governance system, permeates all management structures when it comes to managing the company's leading role in the offering. The 
components of the TQM system are: planning, analysis, evaluation and quality control of products. A schematic representation of the TQM system is shown in Figure 1.

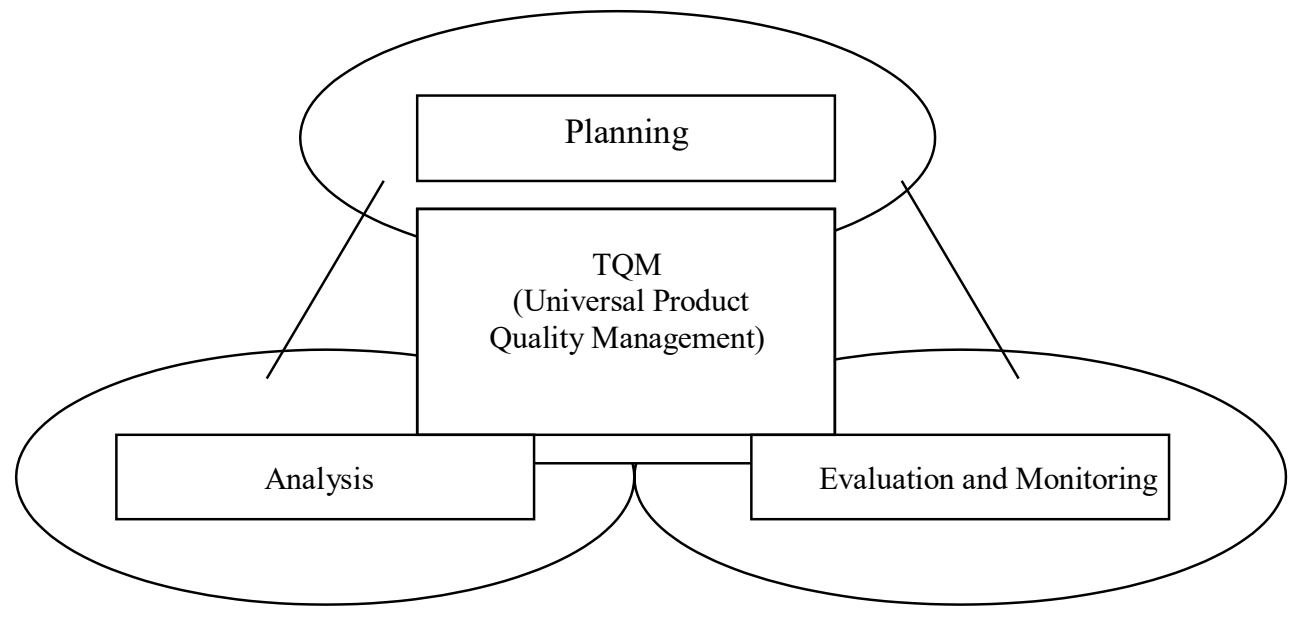

Fig. 1. The main elements of product quality management in the TQM system

According to the TQM philosophy, the effectiveness of quality management depends on three main conditions:

- A deep understanding of the highest official in the company needs constant quality improvement;

- Investing not in equipment, but in people;

- Transformation or special creation of organizational structures for overall quality management.

Quality assurance in the TQM system is understood as a system of measures that constantly supports the confidence of consumers in the quality of products. So, the role of training people and employees increases significantly.

As shown in Figure 2, the consumer is at the center of three important aspects of the quality system. The figure shows that customer satisfaction can be achieved only if there is harmony between the responsibility of management, staff and material resources and the structure of the quality system.

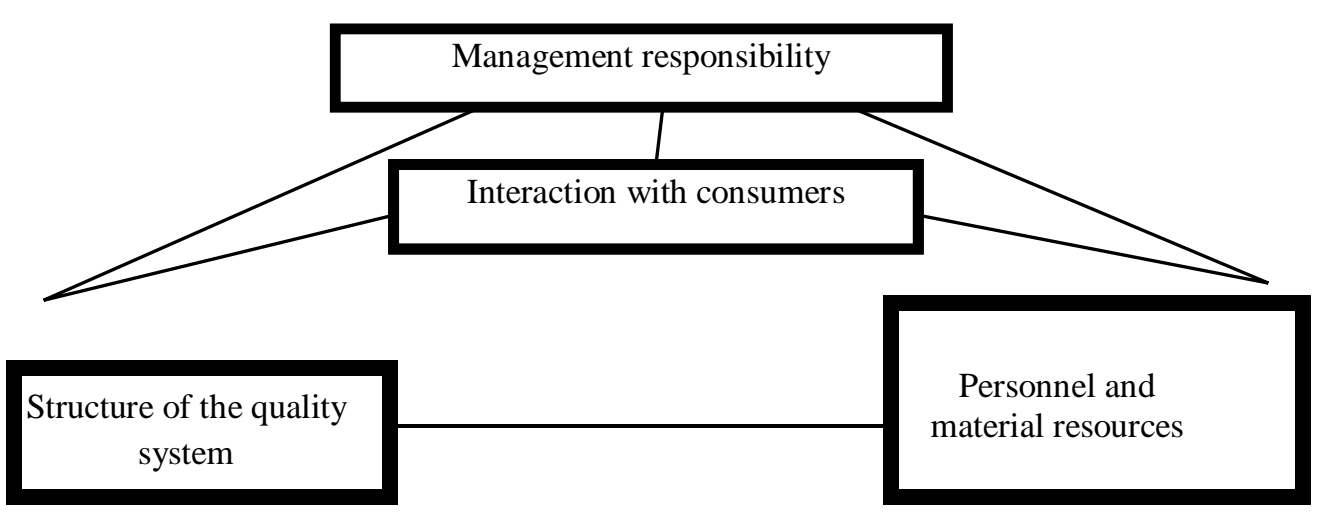

Fig. 2. Key aspects of the quality management system •

The implementation of quality management systems requires significant resources, appropriate training, the development of a large number of scientific studies and the 
awareness of the first head of the company about the need to use such systems. The amount of total expenses (from 35 to 600 thousand UAH) and the duration of certification and application of the quality management system (from 1.5 to 3 years) depends on the size of the company, the type of products, the level of training of personnel.

Now integrated management systems can be created with the participation of such international standards:

- ISO 9000 series (Quality management systems-quality management systems);

- ISO 14000 series (Environmental management systems-Environmental management Systems);

- OHSAS 18000 Series (Occupational Health and Safety Assessment Series-Occupational Health and Safety Management System);

- SA 8000 (Social Accountability - Social Responsibility);

- ISO 17799 series (Information technology-Code of practice for Information security management - Information Technology. Set of rules for information security management);

- HACCP (Hazard Analysis and Critical Control Point);

- GMP (Good Manufacturing Practice);

- FSC (Forest Stewardship Council);

Integrated management systems are based on the application of a systematic and procedural approach to corporate governance, allowing you to link different processes and activities. The activity of any enterprise is associated with risks that cause large losses. The goal of creating an integrated management system is an overall optimal risk management that reduces the necessary material and organizational resources.

Organizations that have correctly built an ISM receive the following benefits:

- Sustainable development of the company through the control and management of the main production risks of the company (reduction of losses caused by them). In modern conditions, the losses from accidents and incidents, the costs of fines and payments for excess environmental pollution are compared with the company's profit and the amount of funding for investment programs.

- Increasing the investment attractiveness of the company. In accordance with the requirements of international financial institutions, the availability and compliance of the company's industrial and environmental safety management system with the international standards ISO 14001 and ISO 45001 are necessary conditions that are monitored during the implementation of special audits.

This methodology can be applied in organizations of all types and sizes, consisting of separate subsidiaries / departments with their own current accounts and independent management. The solution to this problem is to assign the process distribution system to three levels (company-branch-division).

The phase of monitoring the current levels of implementation of quality management solutions is closely related to identifying the needs of the enterprise and the needs of consumers $[17,18]$. To do this, it is necessary to determine the methodological means of measuring deviations from a given quality level. Such tools for controlling production processes are various statistical methods of selective and continuous control, quality control maps, diagrams, Pareto analysis, and much more.

The quality management strategy should focus on the following main points: understanding customer requirements; continuous quality improvement; measurement of the achieved quality level and continuous monitoring; training and retraining initiatives; the importance of organizational change.

The quality management system is based on a set of specific standards - established by regulatory acts on the quantity, quality and conditions of service. The standards contain a list of services, provisions on the procedure for providing services. 
JSC "Kulikovo Milk" is a regional leader in dairy production and positions itself in Ukraine. It specializes in the production of skimmed milk powder, butter, fermented milk products, and more recently, cheese. The production capacity of milk processing is 120-150 tons per day. The dairy mainly operates in the domestic market, but partially exports its products abroad. High-performance imported and domestic equipment is installed in the main workshops.

JSC "Kulikovo Milk" has a linear management structure - the management of actions is carried out by one manager, who makes decisions on all issues, is fully responsible for the results of activities. On the part of the director, the main goals, control, organization, and coordination of the actions of specialists are developed. The analysis of the decisions made is carried out by the chief economist of the department, accounting is kept in the accounting department.

Linear-functional (combined) the type of organizational structure should eliminate the shortcomings of the individual linear and functional types of management structures, in particular such:

- functional links are deprived of the right to directly influence performers;

- they prepare solutions for the line manager, who exercises direct administrative influence on the performers.

The combined structures guarantee a labor market in which the linear management units are required to make decisions and control, and the functional ones-to advise, inform, create, plan (table 1).

Table 1. Volumes of production and sales of products of CJSC "Kulikovo Milk" •

\begin{tabular}{|c|c|c|c|c|c|c|c|c|}
\hline \multirow[t]{2}{*}{$\begin{array}{l}\text { Commo } \\
\text { dity } \\
\text { Group }\end{array}$} & \multicolumn{2}{|c|}{$\begin{array}{l}\text { Volume of } \\
\text { production in } \\
\text { physical terms, } \\
\text { tons }\end{array}$} & \multicolumn{2}{|c|}{$\begin{array}{l}\text { Sales volume in } \\
\text { physical terms, } \\
\text { tons }\end{array}$} & \multicolumn{2}{|c|}{$\begin{array}{l}\text { Production volume in } \\
\text { monetary terms, } \\
\text { (without VAT), } \\
\text { thousand UAH }\end{array}$} & \multicolumn{2}{|c|}{$\begin{array}{l}\text { Sales volume in } \\
\text { monetary terms, } \\
\text { (without VAT), } \\
\text { thousand UAH }\end{array}$} \\
\hline & 2018 & 2019 & 2018 & 2019 & 2018 & 2019 & 2018 & 2019 \\
\hline $\begin{array}{l}\text { Rennet } \\
\text { hard } \\
\text { cheeses }\end{array}$ & 2785 & 3055.5 & 2497 & 2985.7 & 141562 & 188758 & $\begin{array}{c}160925 . \\
2\end{array}$ & $\begin{array}{c}21458 \\
1.1\end{array}$ \\
\hline Butter & 473.2 & 487.6 & 442.4 & 466.8 & 18601.6 & 25789.4 & 23662.6 & $\begin{array}{c}31719 \\
.2\end{array}$ \\
\hline $\begin{array}{c}\text { processe } \\
\mathrm{d} \\
\text { cheeses }\end{array}$ & 83.6 & 39.9 & 78.1 & 36 & 3537.8 & 2390.4 & 3621.2 & $\begin{array}{c}1965 . \\
7\end{array}$ \\
\hline $\begin{array}{c}\text { Milk } \\
\text { sugar } \\
\text { and } \\
\text { Albumin }\end{array}$ & 29.9 & 23,9 & 9 & 21.8 & 611.7 & 906.6 & 139 & 552.9 \\
\hline $\begin{array}{c}\text { normaliz } \\
\text { ed milk }\end{array}$ & 3167.1 & 5386.3 & 3126.6 & 5366.8 & 15699 & 32284.3 & 15052.3 & $\begin{array}{c}33772 \\
.1\end{array}$ \\
\hline $\begin{array}{l}\text { Other } \\
\text { products } \\
\text { and } \\
\text { semi- } \\
\text { finished } \\
\text { products }\end{array}$ & & 25636 & & 25636 & 1879 & 298.2 & 2001.4 & $\begin{array}{c}3617 . \\
3\end{array}$ \\
\hline Total & 6538.8 & 34629.2 & 6153.1 & 34513.1 & 181891.2 & $\begin{array}{c}250426 . \\
6\end{array}$ & $\begin{array}{c}205401 \\
8\end{array}$ & $\begin{array}{c}28620 \\
8.3\end{array}$ \\
\hline
\end{tabular}

The main activities of the company: cheese production area; area for the production of processed cheese; area for the production of butter, not churned milk and low-fat products; area for the production of milk sugar; hardware - reception area. 
The following requirements are established for the quality system in JSC "Kulikovo Milk": defining policies and objectives within the quality framework; quality planning; analysis and measurement of the effectiveness of the implementation of plans; implementation of corrective and preventive measures.

The following requirements are set for production processes: market research and monitoring of needs; development of new types of goods (services); purchase of materials and components; production (provision of services) and quality control; sales and delivery of products to consumers. In addition, there are requirements for providing a quality management system for other types of resources: personnel, equipment and organization; maintain the internal environment. This type of resources also affects the quality of products, and only by managing them can we achieve sustainable customer satisfaction.

The quality of the services offered is influenced by a large number of factors that act independently and interlinked, both at certain phases of the life cycle of the services offered, and at several of them. The factors operating in JSC "Kulikovo Milk" can be grouped into four groups: technical; organizational; economic; subjective.

In the process of making a decision on the organization's quality management system, measures are defined and planned to achieve the goals. The combination of these activities makes up the plan of organizational activity. For each of the activities included in the plan, the conditions for implementation and responsibility for implementation are determined. It is undesirable to include in the plan activities related to the relevant activities in the organization, the implementation of which is provided for by the current documents in the management system.

An important component at the stage of developing a quality management system is to determine the structure and scope of documentation: regulations; quality assurance and improvement plan (including quantitative goals and indicators); quality recommendations; etc.

For successful process management, it is also necessary to define in the quality guidelines: the person responsible for the procedure (the owner of the process); consumer (buyer) procedures and quality requirements-process release; requirements for the input data elements of the process (acquisition and receipt of resources); describe the process (develop a flowchart or process diagram) and its control system; set the sequence and relationship to other processes and the sequence of changes in the process.

For the implementation of the quality policy in JSC "Kulikovo Milk" it is recommended:

- First, update the instructions, where the director of JSC "Kulikovo Milk" will be fully responsible for the quality of products and form the mechanism for building a quality system.

- Secondly, to develop organizational support for the implementation of a quality management system and to combine into a single organizational unit all the processes that are functionally, meaningfully, technologically closely related to the type of activity.

- Third, to ensure innovative processes in the management system, it is proposed to use high-quality temporary associations (groups). They will be a temporary team created to solve a specific product quality problem.

The next important area of implementation of the quality policy in JSC "Kulikovo Milk" is the regulatory support for the creation of quality management systems, namely:

- development and adoption of the quality policy in JSC "Kulikovo Milk", quality guidelines, which should define the components of the quality management system;

- development and self-assessment of the activities of JSC "Kulikovo Milk" as a whole and its employees;

- development of processes that characterize the technology of production and provision of services; 
- improving internal administrative rules;

- Adoption of personnel evaluation and development programs as a basis for ensuring and improving the quality of production.

In order to position yourself at a certain level of quality in relation to competitors, it is desirable to perform the procedure "establishing a quality assessment" (benchmarking), the flow diagram of which is shown in Figure 3.

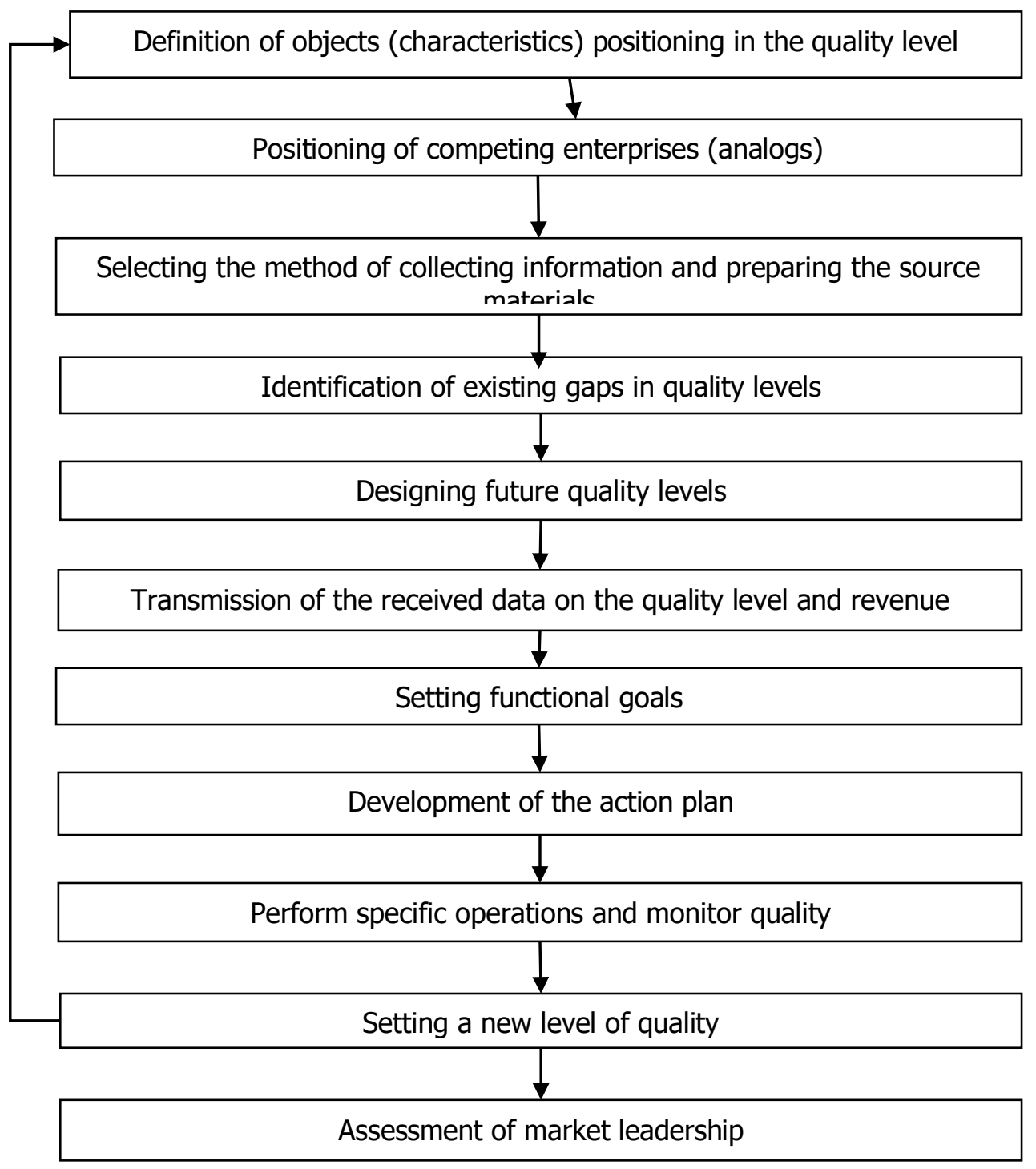

Fig. 3. The proposed procedure for establishing the quality level at JSC "Kulikovo Milk"

According to foreign experience, in addition to the positioning process, the largest Japanese, American and Western European companies use an approach to the development of functional quality. It is based on the coordination of the company's capabilities in organizing, designing, manufacturing and marketing to the requirements of consumers for 
the quality of products and services. The priority in this case is the requirements and expected expectations for the quality level of potential consumers [15].

When building a mechanism for implementing the quality policy in the management system of JSC "Kulikovo Milk", it is necessary to realize that the organization of quality work concerns almost all aspects of the organization as a whole. Since the quality management system actually covers all areas of the organization, then, of course, the processes of creating and implementing a quality management system in the enterprise will be associated with a change in the organizational structure of management. According to many experts in the field of quality and organizational design, the development of the organizational management structure of the enterprise will be carried out in the direction of creating project structures, where the group approach dominates in solving any problems $[19,20]$.

To perform quality tasks, the manager creates a service (or division) for the quality system, ensures effective product quality management, its evaluation and improvement at all stages of production. It is necessary to clearly define the general and personal responsibility and authority of all employees, on whose work the quality of the services provided depends. At the same time, there must be a need for effective relationships between consumers and suppliers in all aspects of their interaction inside and outside the organization. The established responsibility and authority should correspond to the tools and methods of ensuring the quality of the goods.

However, the manager should be responsible for developing the quality system requirements. It should be directly or through a designated employee who is responsible for the implementation of the quality system, its verification, continuous measurement of parameters and analysis for improvement. While responsible personnel can help achieve quality, they do not create quality - this is only part of the quality system. The scope of the system covers all functions, and continuous improvement of quality requires the participation, dedication and effective interaction between all employees of the service organization.

Thus, the quality management system is a personnel management system, which should be supplemented by the implementation of a number of motivational measures, because this requires not only having qualified specialists, but also getting them interested in effectively realizing their potential.

\section{Conclusions}

Building and implementing an integrated quality management system in an enterprise is a complex process that requires significant time and resources and is aimed at continuous improvement and improvement of activities. The content of building a quality management system is to recognize the processes on which the quality of products or services depends. There are two main goals for developing a quality management system. The first is to optimize the work of the enterprise and, in particular, to ensure the competitiveness of products and services, to increase the efficiency of production. The second goal is to demonstrate to all potential consumers the ability to consistently produce products of a certain level of quality that meets all their requirements and needs. The main regulatory documents that establish the main requirements for quality management systems are the international standards of the ISO series and the state standards in Ukraine developed on their basis.

The following factors influence the development of the quality management system and its application in the organization:

- The environment, changes in this environment and the risks associated with this environment; 
- The change needs of the organization;

- The specific goals of the organization and its mission;

- Existing production or service delivery processes;

- The size and structure of the organization.

\section{References}

1. J. Priede, Procedia-Social and Behavioral Sciences, 58, 1466 (2012)

2. V. Siva, I. Gremyr, B. Bergquist, R. Garvare, T. Zobel, R. Isaksson, Journal of Cleaner Production, 138, 148 (2016)

3. W. Fan, F. Geerts, Foundations of data quality management. Synthesis Lectures on Data Management, 4(5), 1 (2012)

4. G. Abuselidze, Y. Bilyak, N. K. Mračkovskaya, Studies of Applied Economics 39(6), (2021)

5. A. Slobodianyk, G. Abuselidze, V. Lymar, E3S Web of Conferences 234, 00001 (2021)

6. C. Zehir, Ö.G. Ertosun, S. Zehir, B. Müceldilli, Procedia-Social and Behavioral Sciences 41, 273 (2012)

7. V. Nanda, Quality management system handbook for product development companies (CRC press, 2005)

8. M.S. Ilkay, E. Aslan, International Journal of Quality \& Reliability Management 29(7), 753 (2012)

9. J.A. Gimenez-Espin, D. Jiménez-Jiménez, M. Martinez-Costa, Total Quality Management \& Business Excellence 24(5-6), 678 (2013)

10. A. Slobodianyk, G. Abuselidze, E3S Web of Conferences 135, 01019 (2019)

11. P. Kumar, J. Maiti, A. Gunasekaran, International Journal of Quality \& Reliability Management 35(5), 1034(2018)

12. G. Abuselidze, I. Gogitidze,E3S Web of Conferences 166, 13013 (2020)

13. G. Abuselidze, A. Slobodianyk, E3S Web of Conferences 210, 15016 (2020).

14. R. I. Buryak, Bulletin of the Academy of Labour and social relations of the Federation of Trade Unions of Ukraine 3-4, 36 (2015)

15. V. P. Gorevoy, Quality Potential Management. Training manual (Kiev, 2018)

16. Legislation of Ukraine. On Consumer Rights Protection. (Verkhovna Rada of Ukraine, 2021)

17. A. Simon, M. Bernardo, S. Karapetrovic, M. Casadesús, Journal of Cleaner Production 19(17-18), 2057 (2011)

18. G. Abuselidze, A. Slobodianyk, E3S Web of Conferences 164, 09036 (2020).

19. Legislation of Ukraine. On Quality and Safety of Food Products and Food Raw Materials. (Verkhovna Rada of Ukraine, 2021)

20. Legislation of Ukraine. On Standardization. (Verkhovna Rada of Ukraine, 2020) 